J. Lake Sci. (湖泊科学) , 2016, 28(5): 961-971

DOI 10. 18307/2016. 0505

(C) 2016 by Journal of Lake Sciences

\title{
夏季滇池和入滇河流氮、磷污染特征"
}

\author{
余丽燕 ${ }^{1}$,杨 浩 $^{1}, \mathbf{M}^{\text {昌春 }}{ }^{\text {*** }}$, 黄 涛 $^{1 * *}$, 余艳红 ${ }^{2}$, , 姜泉良 $^{1}$, 刘大庆 ${ }^{1}$, 李帅东 ${ }^{1}$ \\ (1: 南京师范大学, 南京 210023) \\ (2:云南省环境科学研究院, 昆明 650032$)$
}

\begin{abstract}
摘 要: 为探讨滇池人湖河流水体营养盐空间分布特征及其对滇池水体富营养化的影响, 2014 年 7 月采集了人滇 4 类典 型河流 ( 城市纳污型河流、城乡结合型河流、农田型河流、村镇型河流) 及滇池水样, 分析其氮、磷浓度. 结果表明: 4 条人 湖河流总氮 (TN) 、总磷 (TP)、硝态氮和氨氮污染均较严重; 河流水体中 TN、TP 平均浓度大小为: 农田型河流 (大河) > 村 镇型河流 (柴河) >城乡结合型河流 (宝象河) >城市纳污型河流 (盘龙江), 其中农田型河流 (大河) 水体 TN、TP 污染最为 严重; 在夏季, 4 条人湖河流水体中 TN、TP 浓度从上游向下游增加趋势比较明显, 表明氮、磷沿河流不断富集; 氮磷比分 析表明, 夏季河流输人氮、磷营养盐有利于藻类的生长, 并且滇池浮游植物生长主要受 TN 浓度限制; 夏季滇池南部人湖 河流水体的 TN TP 浓度高于北部人湖河流, 该特征与滇池水体中 TN、TP 污染分布状况相反, 推测滇池北部富营养化的 主要影响因素是内源释放. 因此, 在今后的滇池水体富营养化研究中, 应对滇池内源释放进行深人研究.
\end{abstract}

关键词: 滇池; 人湖河流;营养状况;氮; 磷;污染

\section{Characteristic of nitrogen and phosphorous pollution in Lake Dianchi and its inflow rivers in summer}

YU Liyan ${ }^{1}$, YANG Hao $^{1}$, HUANG Changchun ${ }^{1 * *}$, HUANG Tao ${ }^{1 * *}$, YU Yanhong ${ }^{2}$, JIANG Quanliang ${ }^{1}$, LIU Daqing $^{1} \&$ LI Shuaidong ${ }^{1}$

(1: Nanjing Normal University, Nanjing 210023, P.R.China)

(2: Environmental Science Research Institute of Yunnan Province, Kunming 650032, P.R.China)

\begin{abstract}
To investigate the spatial distribution of nutrients in the inflow rivers and their influence on the eutrophication of Lake Dianchi, water samples were collected from Lake Dianchi and four different types of the inflow rivers during July of 2014. The four different types of rivers were named as the river in the urban areas, the river in the combination of urban and rural areas, the river dominated by non-point source pollution, and the river dominated by sewage pollution in town and village. The results indicated that, total nitrogen ( TN), total phosphorus ( TP), nitrate nitrogen, and ammonium nitrogen concentrations from the four inflow rivers were very high. The mean concentrations of TN and TP from these inflow rivers were in the order: rivers dominated by nonpoint source pollution (Dahe River) > rivers dominated by sewage pollution in town and village (Chaihe River) $>$ rivers in the combination of urban and rural areas ( Baoxiang River) > rivers in the urban areas (Panlong River). The TN and TP concentrations from the rivers dominated by non-point source pollution (Dahe River) were the highest. In summer, it is clearly that the TN and TP concentrations increased from the upstream to the downstream in all four inflow rivers, which means that the TN and TP constantly accumulated. The ratio of nitrogen and phosphorus showed that both TN and TP were sufficient for algal growth from all inflow rivers in summer, but the algal growth in Lake Dianchi was limited by TN. The TN and TP concentrations from the southeastern inflow rivers were higher than those from the northwestern rivers, but the law was opposite in Lake Dianchi. Therefore, we speculated that the internal pollutant sources are the major cause of eutrophication of Lake Dianchi. The deeply researches should focus on the internal pollutions for the study on the eutrophication of Lake Dianchi in the future.
\end{abstract}

* 国家自然科学基金项目(41503075,41571324)、中国博士后基金面上项目(2015M581826)和云南省环境科学研究 院 (中国昆明高原湖泊国际研究中心) 开放基金项目联合资助. 2015-09-14 收稿; 2015-12-09 收修改稿. 余丽 燕 ( $1990 \sim$ ), 女, 硕士;E-mail : 1606695310@ qq.com.

** 通信作者;E-mail:huangchangchun@ njnu.edu.cn, E-mail:09392@ njnu.edu.cn. 
Keywords: Lake Dianchi; inflow rivers; nutrition status; nitrogen; phosphorus; pollution

水体富营养化是国际社会共同关注的水环境污染问题 ${ }^{[1-2]}$, 如何有效地治理水体富营养化已成为世界 性难题 ${ }^{\left[{ }^{3}\right]}$. 众所周知,氮、磷是水体富营养化最为主要的限制性因子 ${ }^{[4]}$. 湖泊营养化的控制与机制 ${ }^{[5]}$, 尤其 是匈牙利的 Balaton 湖 ${ }^{[6]}$ 等浅水湖泊富营养化的成功治理, 为湖泊水体的富营养化治理提供了宝贵的参考 经验. 湖泊营养盐的富集, 包括外源输人 (人类活动和干、湿沉降) 和内源释放 (物理、化学、生物等过程), 是湖泊富营养化发生的根本要素 ${ }^{[7]}$. 因此, 外源输人和内源释放都受到了研究者的广泛关注. 目前, 相关研 究主要集中在湖泊水体本身内源污染负荷方面 ${ }^{[8]}$, 而对湖泊富营养化程度的外部影响因素, 尤其是人湖河 流水质营养状况对湖水富营养化的影响研究较少. 人湖河流作为氮和磷转移到湖泊中的主要路径, 集中了 所在流域的各种点源污染 (工业污染、生活污水等) 和面源污染 (农业生产污水) ${ }^{[9]}$. 为此, 全面了解人湖河 流氮、磷营养盐空间分布及滇池污染状况,将有助于制定合理的水污染治理措施.

滇池流域是云南省人口最密集、经济最发达的地区, 由于毗邻昆明主城区, 滇池水质一直受到人类活动 的严重影响. 随着污染物产生量的迅速增加, 富营养化已经成为滇池主要的环境问题 ${ }^{[10]}$. 滇池位于整个滇 池流域的下部, 主要有宝象河、马料河等 20 多条河流汇人湖体. 已有研究表明, 大量氮、磷等营养物质通过 流域的地表径流进人滇池, 进一步加重了水体富营养化 ${ }^{[11]}$. 自 1980s 以来, 有关滇池及其流域的富营养化研 究逐渐深人 ${ }^{[12-16]}$, 王红梅等 ${ }^{[17]}$ 从时间尺度分析了滇池水体富营养化状况, 结果表明滇池水体富营养化程度 在逐年加重; 刘勇等 ${ }^{[18]}$ 从沉积物角度研究了滇池富营养化, 表明自 $1950 \mathrm{~s}$ 以后滇池开始由中营养化向富营 养化过渡; 王佳音等 ${ }^{[19]}$ 研究了八滇河流大河周边地下水氮污染的变化, 揭示了大河周边农田地下水 3 种不 同氮组分主要以硝酸盐形态存在, 地下水中及滇池大河流域地下水 3 种形态氮浓度在空间和时间上遵循一 定的变化规律. 目前的相关研究主要集中于人湖河流时间尺度上营养现状的变化特征, 或者局限于湖体水 质分析, 而缺乏多条人滇池河流营养盐的空间变化、人湖河流外源污染和湖体氮、磷污染特征的对比研究. 为此, 有必要综合分析滇池湖泊水体氮、磷空间污染特征和人滇池河流水质营养状况的空间分布特征.

湖泊富营养化将有可能导致水体藻类大量生长, 从而形成“水华”. 夏季, 藻类开始大量繁殖, 而氮、磷是 其生长最重要的控制因素, 了解水体氮、磷营养盐空间分布特征, 将有助于评估 “水华” 暴发风险. 本研究拟 对滇池人湖 4 类典型河流 ( 城市纳污河流、城乡结合部河流、农田河流、村镇河流) 氮、磷营养盐的空间分布 规律以及滇池污染来源进行分析, 利用氮磷比 (TN/TP) 解析 4 条河流夏季水质的营养现状, 探讨滇池流域 人湖河流的富营养化污染的空间分布特征及其对滇池水体富营养化的影响, 为该流域规划以及水质保护方 案的制定提供科学依据.

\section{1 材料与方法}

\section{1 研究区域}

滇池 ( $\left.24^{\circ} 40^{\prime} \sim 25^{\circ} 2^{\prime} \mathrm{N}, 102^{\circ} 36^{\prime} \sim 102^{\circ} 47^{\prime} \mathrm{E}\right)$ 位于第二级阶梯云贵高原中部, 是云南高原最大的淡水湖, 流域面积 $2920 \mathrm{~km}^{2}$, 滇池湖体呈南北分布, 略呈弓形, 面积 $309.5 \mathrm{~km}^{2}$, 南北向长 $40 \mathrm{~km}$, 平均深度 $5.3 \mathrm{~m}^{[20]}$. 滇 池大小人湖河流共 120 多条,多发源于流域北部、东部和南部山地 ${ }^{[21]}$, 大部分人湖河流流经人口密集的城 镇、乡村以及磷矿区, 最后呈向心状注人滇池.

选择滇池人湖 4 类典型河流 ( 城市纳污河流、城乡结合部河流、农田河流和村镇河流), 分别代表不同人 滇河流的营养物含量和污染源类型. 其中, 盘龙江是一条城市纳污河流, 自北向南纵穿昆明城而过, 从而成 为昆明四城区的分界线, 该河流主要接纳昆明城区点源生活污水; 宝象河汇水区处于城乡结合部, 接受城市 点源与农业面源污染; 大河位于连片农田区域的中间部位, 周围基本无居住区、乡镇企业或规模化畜禽养殖 基地; 柴河属于村镇河流,其村镇居民集中居住区周边无集中污水处理系统 ${ }^{[22]}$.

\section{2 样品采集}

通过对 4 条典型河流盘龙江 (PLJ)、宝象河 (BXH)、大河 (DH) 和柴河 $(\mathrm{CH})$ 及滇池 $(\mathrm{DC})$ 湖体进行实地 考察、调研, 并严格按照地表水和污水监测技术规范 ( HJ/T 91-2002) 及文献 $[23]$ 确定每条河流的采样点 (图 1). 盘龙江采样点编号为 PLJ1 PLJ12, 宝象河采样点编号为 BXH1 BXH13, 大河采样点编号为 DH1 
DH12, 柴河采样点编号为 CH1 CH9, 各断面采样点均 自上游到下游依次编号. 滇池采样点编号为 DC1 DC28. 采样时间为 2014 年 7 月 9 日- 7 月 16 日,所 采集的水样送云南省环境科学研究院, $24 \mathrm{~h}$ 内完成 分析检测工作.

\section{3 测试分析与数据处理}

水样测试指标包括总氮 $(\mathrm{TN})$ 、氨氮 $\left(\mathrm{NH}_{3}-\mathrm{N}\right)$ 、硝 态氮 $\left(\mathrm{NO}_{3}^{-}-\mathrm{N}\right)$ 和总磷 $(\mathrm{TP})$ 浓度, 均按国家标准方法测 定. 按照国家《地表水环境质量标准》(GB3838$2002)^{[24]}$ (表 1) 评估滇池 4 条人湖河流及其氮、磷污 染情况. 采用 Origin 8.0 软件进行图像绘制, 同时使 用 ArcGIS 10.1 对滇池水样指标 TN、TP 浓度进行空 间插值分析, 以便了解整个滇池氮、磷浓度的空间变 化趋势.

\section{2 结果与分析}

\section{1 入滇河流和滇池污染总体特征}

4 条人滇河流与滇池水体中不同形态的氮、磷平 均浓度存在较大差异. 4 类河流 TN 平均浓度在 $3.58 \sim 11.11 \mathrm{mg} / \mathrm{L}$ 之间; $\mathrm{NH}_{3}-\mathrm{N}$ 平均浓度在 $1.18 \sim$ $2.84 \mathrm{mg} / \mathrm{L}$ 之间, 高于 III 类水质浓度限值 ( $1.0 \mathrm{mg}$ / $\mathrm{L}$ ); $\mathrm{NO}_{3}^{-}-\mathrm{N}$ 平均浓度在 1.76 7.67 mg/L 之间 (表 2). 4 类河流水体中的 $\mathrm{NO}_{3}^{-}-\mathrm{N}$ 均为氮素的主要赋存形 式,盘龙河、宝象河、大河和柴河水体中的 $\mathrm{NO}_{3}^{-}-\mathrm{N}$ 浓 度占总氮浓度比例分别为 $49.1 \% 、 54 \% 、 69 \%$ 和 79\%。 水体中氮素多以还原态及氧化态存在, 还原态 $\mathrm{NH}_{3}$ $\mathrm{N}$ 浓度降低而氧化态 $\mathrm{NO}_{3}^{-}-\mathrm{N}$ 浓度上升, 在一定程度

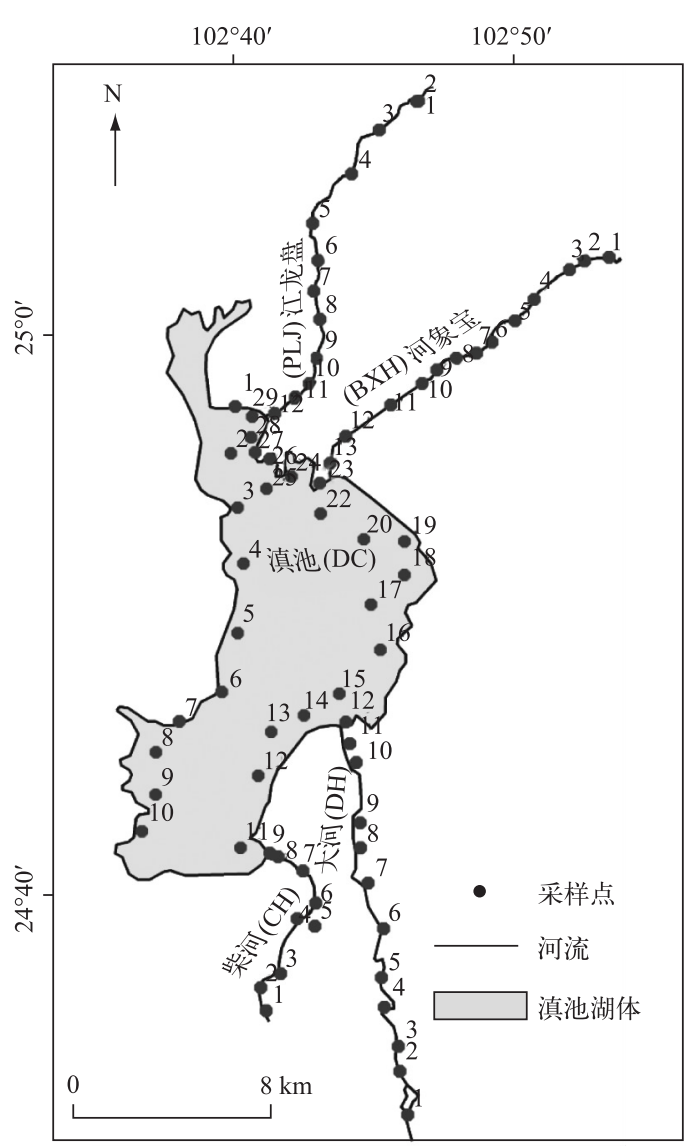

图 1 滇池流域采样点分布

Fig. 1 Sampling sites in Dianchi watershed 上表明水体环境氧化能力有提升的趋势 ${ }^{[25]}$. TP 平均 浓度在 $0.18 \sim 0.47 \mathrm{mg} / \mathrm{L}$ 之间, 其中, 盘龙江 TP 平均浓度最低 $(0.18 \mathrm{mg} / \mathrm{L})$, 低于 III 类水质浓度限值 $(0.2 \mathrm{mg} /$ $\mathrm{L})$. 滇池水体中 $\mathrm{TN}$ 浓度在 $1.14 \sim 5.54 \mathrm{mg} / \mathrm{L}$ 之间, 平均浓度为 $2.37 \mathrm{mg} / \mathrm{L} ; \mathrm{NH}_{3}-\mathrm{N}$ 平均浓度为 $0.38 \mathrm{mg} / \mathrm{L}$; $\mathrm{NO}_{3}^{-}-\mathrm{N}$ 平均浓度为 $0.41 \mathrm{mg} / \mathrm{L}$; TP 浓度在 $0.19 \sim 0.69 \mathrm{mg} / \mathrm{L}$ 之间, 平均浓度为 $0.29 \mathrm{mg} / \mathrm{L}$ (表 2). 从 7 月 $\mathrm{TN}$ 、 $\mathrm{TP}$ 浓度变化来看, 4 条河流和滇池 $\mathrm{TN}$ 与 $\mathrm{TP}$ 平均浓度大都超出地表水 $\mathrm{V}$ 类标准 (表 1 ), 并远超过国际上广 泛认可的发生水体富营养化的临界浓度 ( TN 浓度为 $0.2 \mathrm{mg} / \mathrm{L}$, TP 浓度为 $0.02 \mathrm{mg} / \mathrm{L})^{[26]}$, 表明氮、磷营养盐 完全可以满足藻类生长的需要, 一旦温度、光照、水动力等条件适宜, 藻类就可能快速生长、繁殖, 从而导致 水质恶化 ${ }^{[27]}$.

表 1 地表水总氮、总磷和氨氮标准

Tab. 1 Criteria of total nitrogen, total phosphorus and ammonia in surface water

\begin{tabular}{lccccc}
\hline 项目 & I 类 & II 类 & III 类 & IV 类 & V 类 \\
\hline $\mathrm{TN} /(\mathrm{mg} / \mathrm{L})$ & 0.2 & 0.5 & 1.0 & 1.5 & 2.0 \\
$\mathrm{TP} /(\mathrm{mg} / \mathrm{L})$ & 0.02 & 0.10 & 0.20 & 0.30 & 0.40 \\
& $($ 湖、库 0.010$)$ & (湖、库 0.025$)$ & (湖、库 0.050$)$ & (湖、库 0.100$)$ & $($ 湖、库 0.200$)$ \\
$\mathrm{NH}_{3}-\mathrm{N} /(\mathrm{mg} / \mathrm{L})$ & 0.15 & 0.50 & 1.00 & 1.50 & 2.00 \\
\hline
\end{tabular}


表 2 滇池及其 4 类不同人湖河流水体中的氮、磷浓度

Tab.2 Nitrogen and phosphorus concentrations in water of Lake Dianchi and four different kinds of inflow rivers

\begin{tabular}{|c|c|c|c|c|c|c|c|c|}
\hline \multirow{2}{*}{ 采样区域 } & \multicolumn{2}{|c|}{$\mathrm{TN} /(\mathrm{mg} / \mathrm{L})$} & \multicolumn{2}{|c|}{$\mathrm{TP} /(\mathrm{mg} / \mathrm{L})$} & \multicolumn{2}{|c|}{$\mathrm{NH}_{3}-\mathrm{N} /(\mathrm{mg} / \mathrm{L})$} & \multicolumn{2}{|c|}{$\mathrm{NO}_{3}^{-}-\mathrm{N} /(\mathrm{mg} / \mathrm{L})$} \\
\hline & 范围 & 平均值 & 范围 & 平均值 & 范围 & 平均值 & 范围 & 平均值 \\
\hline 盘龙江 & $1.28 \sim 5.22$ & 3.58 & $0.06 \sim 0.34$ & 0.18 & $0.01 \sim 3.11$ & 1.57 & $1.03 \sim 2.15$ & 1.76 \\
\hline 宝象河 & $1.82 \sim 6.43$ & 4.66 & $0.06 \sim 0.41$ & 0.20 & $0.10 \sim 1.99$ & 1.18 & $0.59 \sim 3.79$ & 2.52 \\
\hline 大河 & $5.01 \sim 19.12$ & 11.11 & $0.28 \sim 0.89$ & 0.47 & $0.13 \sim 9.84$ & 2.84 & $4.07 \sim 8.64$ & 7.67 \\
\hline 柴河 & $4.04 \sim 12.62$ & 9.14 & $0.18 \sim 0.59$ & 0.37 & $0.23 \sim 2.82$ & 1.23 & $3.29 \sim 9.57$ & 7.26 \\
\hline 滇池 & $1.14 \sim 5.54$ & 2.37 & $0.19 \sim 0.69$ & 0.29 & $0.22 \sim 1.00$ & 0.38 & $0.23 \sim 1.27$ & 0.41 \\
\hline
\end{tabular}

\section{2 入滇河流和滇池水体 TN 浓度的空间变化特征及污染状况}

本研究是从河流上游到下游进行分段采样. 4 条河流在夏季 TN 浓度从上游向下游逐渐增加, 这种增加 趋势在大河最为显著,其次在柴河. 逐点分析 TN 浓度,宝象河和盘龙江 TN 浓度变化幅度不大,盘龙江上游 4 个样点 $\mathrm{TN}$ 浓度值都小于 $\mathrm{V}$ 类水质浓度限值 $(2 \mathrm{mg} / \mathrm{L})$, 下游 8 个样点 $\mathrm{TN}$ 平均浓度都超过 $\mathrm{V}$ 类水质浓度限 值. 宝象河 13 个采样点水体的 TN 浓度从上游到下游变化趋势相对较缓, 大河与柴河水体的 TN 浓度变化较 大, 其中, 大河 $\mathrm{TN}$ 浓度最大值出现在第 8 个样点; 柴河 9 个采样点 $\mathrm{TN}$ 浓度变化整体上与大河类似 (图 2a). 4 条河流水体氮素的人湖平均浓度以农田型河流 (大河) 的贡献最大, 但不同的氮形态变化特征存在较大差 异. 对 $\mathrm{TN}$ 和 $\mathrm{NO}_{3}^{-}-\mathrm{N}$ 而言, 人湖平均浓度排序为: 大河>柴河>宝象河 >盘龙江. $\mathrm{NH}_{3}-\mathrm{N}$ 平均浓度分布规律为: 大河流域>盘龙江>柴河>宝象河 (图 2b). 4 条河流 3 种形态氮的人湖总量差异主要与流域类型的特性有关.
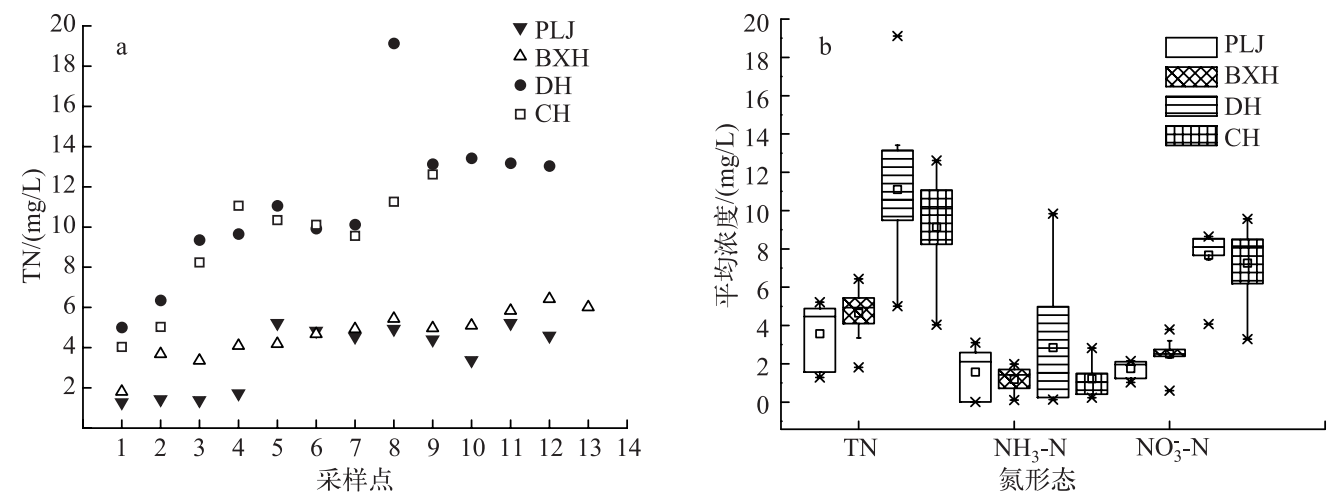

图 2 滇池 4 类不同人湖河流水体中总氮、氨氮及硝态氮浓度

Fig. 2 Total nitrogen, ammonia nitrogen and nitrate nitrogen concentrations in the water of four different kinds of inflow rivers from Lake Dianchi

使用 ArcGIS 10.1 对滇池水体 TN 浓度进行空间插值分析, 获得滇池水体氮、磷浓度空间变化趋势. 滇池 水体 TN 均值浓度空间分布具有差异性, 滇池水体 TN 浓度由北部向南部呈衰减趋势 (图 3). 滇池北部水体 $\mathrm{TN}$ 浓度在 1.32 5.55 mg/L 之间, 平均浓度为 $3.02 \mathrm{mg} / \mathrm{L}$. 滇池南部水体 $\mathrm{TN}$ 浓度在 $1.14 \sim 1.71 \mathrm{mg} / \mathrm{L}$ 之间, 平 均浓度为 $1.36 \mathrm{mg} / \mathrm{L}$.

\section{3 入滇河流和滇池水体 TP 浓度的空间变化特征及污染状况}

夏季各河流水体中 TP 浓度从上游向下游逐渐升高, 变化趋势与 TN 浓度类似 (图 4a). 逐点分析 TP 浓 度, 宝象河和盘龙江 TP 浓度变化幅度不大, 盘龙江上游 4 个采样点水体的 TP 浓度都低于 II 类水质浓度限 值 $(0.1 \mathrm{mg} / \mathrm{L})$, 下游 8 个样点 TP 浓度大于 II 类水质浓度限值. 宝象河 13 个采样点水体的 TP 浓度从上游到 下游变化趋势相对较缓, TP 浓度峰值拐点出现在第 7 个采样点, 其浓度高达 $0.41 \mathrm{mg} / \mathrm{L}$. 大河与柴河 TP 浓 度变化较大, 其中, 大河水体 TP 浓度最大值出现在第 8 个样点; 柴河 9 个采样点 TP 浓度变化整体上与大河 
类似,最大值出现在采样点 $7(0.59 \mathrm{mg} / \mathrm{L})$. 农田型河流 (大 河) 是人湖磷素的主要贡献者, 进人滇池的 TP 平均浓度排 序为: 大河>柴河>宝象河>盘龙江 (图 4b), 表明农业汇水区 河流的平均浓度贡献率明显高于城市汇水区河流.

滇池水体中 TP 平均浓度的空间分布具有差异性,由北 部向南部呈衰减的趋势 ( 图 5). 滇池北部水体中 TP 浓度在 $0.21 \sim 0.69 \mathrm{mg} / \mathrm{L}$ 之间, 平均浓度为 $0.35 \mathrm{mg} / \mathrm{L}$. 滇池南部水 体中 TP 浓度为 $0.19 \sim 0.25 \mathrm{mg} / \mathrm{L}$, 平均浓度为 $0.22 \mathrm{mg} / \mathrm{L}$.

\section{4 入滇典型河流以及滇池水体氮、磷比例关系}

TN/TP (质量比) 是分析河流水体浮游植物的生长态势 及其营养盐限值因子和水体浮游植物营养结构特征的重要 指标. 有学者将富营养化评估的标准划分 3 个区间: (1) 当 TN/TP 小于 7 10, 氮元素成为浮游植物生长的限制因子. (2) TN/TP 介于 23 30 之间, 磷元素成为水体植物生长的 限制因子. (3) TN/TP 介于两者之间为水体植物合适的生 长范围 ${ }^{[28-29]}$. 不同流域类型的 4 条河流夏季 TN/TP 基本上 介于 7 30 之间 (图 6), 说明夏季各条河流水质整体上适合 浮游藻类的生长. 而滇池大部分采样点水体的 TN/TP 小于 7 , 说明氮元素成为滇池浮游植物生长的限制因子, 因此对 氮污染进行控制更有利于滇池水体富营养化的控制.

\section{3 讨论}

\section{1 影响入滇河流水体 TN、TP 浓度空间变化的主要因素}

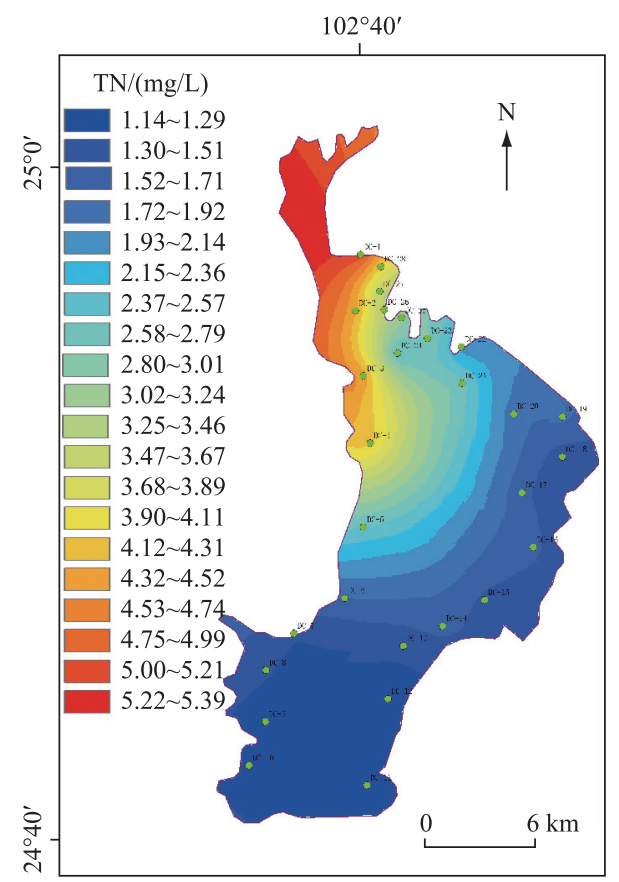

图 3 滇池水体中 $\mathrm{TN}$ 浓度的空间分布 Fig.3 Spatial distribution of total nitrogen concentration in the water of Lake Dianchi

位于北部的宝象河和盘龙江水体氮、磷浓度低于南部的柴河和大河 (图 2 5), 水体 TN 、TP 浓度差异是 由不同类型的河流和每条河流不同河段的区域异质性导致的. 城乡结合型河流(宝象河) 和城市纳污型河流 (盘龙江) 流经地区多为城镇居民区, 治污力度较大导致营养盐浓度相对较低 ${ }^{[30]}$; 而农田型河流 (大河) 和村 镇型河流 (柴河) 流经地区多为集约化农业区, 化肥的大量使用以及禽畜废弃物的直接排放造成水体中氮、 磷等营养盐浓度较高. 有研究表明, 农业上长期施用高量氮肥和畜禽养殖废弃物的直接排放是造成水中氮 污染的重要原因之一 ${ }^{[31]}$.

夏季 4 条河流水体中 TN 和 TP 浓度从上游向下游逐渐升高,但各河流在不同河段的变化特征存在差
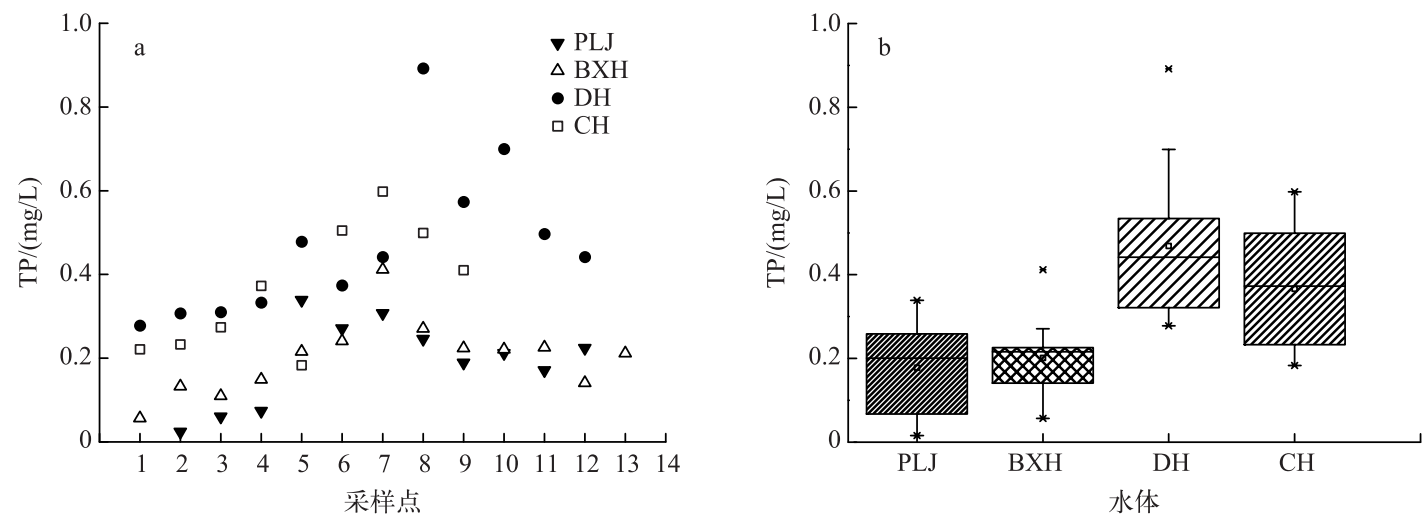

图 4 滇池 4 类人湖河流水体中的总磷浓度

Fig.4 Total phosphorus concentrations in water of four different kinds of inflow rivers from Lake Dianchi 


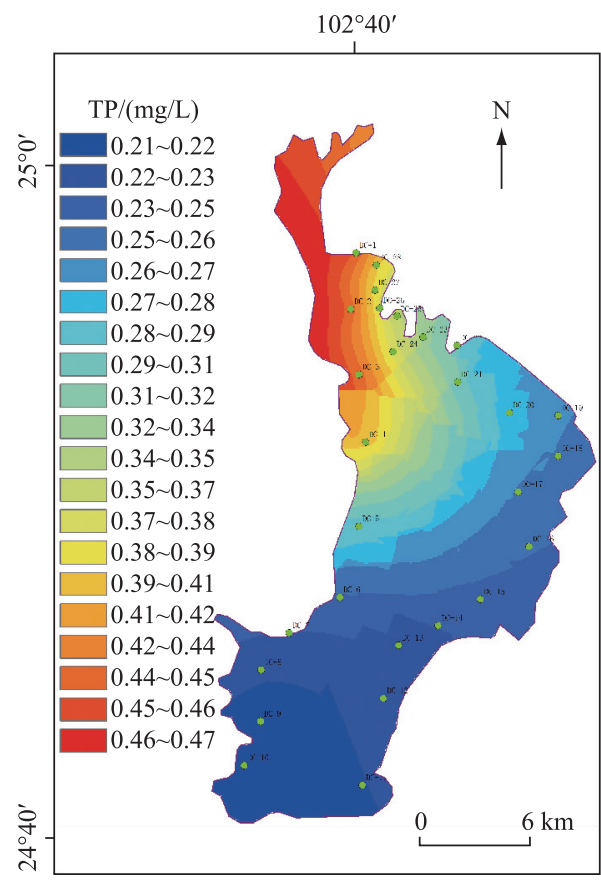

图 5 滇池水体 $\mathrm{TP}$ 浓度的空间分布

Fig.5 Spatial distributions of total phosphorus concentration in water of Lake Dianchi
异. 具体差异性和影响因素为:

城市纳污型河流 (盘龙江) 上游 4 个采样点水体 TN 、TP 浓度分别低于 $\mathrm{V}$ 类和 II 类水质标准, 主要因为上游河段作 为昆明市主要饮用水源保护区, 实行封闭式管理, 污染较 小; 而其下游 8 个采样点水体 $\mathrm{TN}$ 、 $\mathrm{TP}$ 浓度分别超过 $\mathrm{V}$ 类和 II 类水质标准, 符合城市纳污河流沿途不断接受污水排放 的实际情况 ${ }^{[32]}$.

城乡结合型河流 (宝象河) 13 个采样点水体中 TN、TP 浓度从上游到下游变化趋势相对较缓. 宝象河是滇池东部 城乡结合部人湖河流, 沿途接纳城市点源与农业面源污染, 因此城市污染与农业污染对其均有影响 ${ }^{[33]}$. TP 浓度峰值 拐点出现在第 7 个采样点, 结合采样时间、天气状况以及采 样点地形特征 (大面积无植被覆盖的红黄壤山坡), 主要是 因为夏季降雨量较大, 容易形成明显的地表径流 ${ }^{[34]}$, 使山 坡水土流失严重,进而使大量易溶解性磷随径流进人水体.

村镇型河流 (柴河) 9 个采样点水体 TN、TP 浓度从上 游到下游呈先增后减的趋势, TP 浓度最大值出现在采样点 7 , 主要原因是其位于磷矿分布区域. 样点 4 与样点 7 之间 河段的 TN 浓度有所降低, 可能是以硝态氮为主的水体自净 作用的结果 ${ }^{[35]}$.

农田型河流 (大河) 12 个采样点水体 TN、TP 浓度变化 基本符合农田河流营养盐从上游到下游不断累积的特征, 其中, 第 8 个采样点水体 TN、TP 浓度突然增加, 这主要是

由于该采样点周围有农田广布,是农业面源污染导致的 ${ }^{[36]}$.

\section{2 影响入滇河流水体氨氮、硝态氮浓度空间变化的主要因素}

对于 TN、TP 而言, 农业汇水区为主的大河与柴河人湖水体平均浓度明显高于城市汇水区为主的盘龙江 和宝象河, 且总体变化趋势一致 (图 2a、图 4a), 但不同形态的氮总体变化趋势存在明显差异, 这主要与河流 类型特征有关. 4 条河流水体的 $\mathrm{NH}_{3}-\mathrm{N}$ 浓度总体上呈现从上游到下游波动增加的变化趋势 (图 7a). 有研究 表明, 河流中 $\mathrm{NH}_{3}-\mathrm{N}$ 主要来源于城市生活污水和工业废水以及由水土流失和农田施肥造成的氮素流失 ${ }^{[37]}$, 但不同类型河流的变化趋势各异. 农田型河流 (大河) 水体的氨氮浓度相对较高, 说明丰水期的夏季 $\mathrm{NH}_{3}-\mathrm{N}$

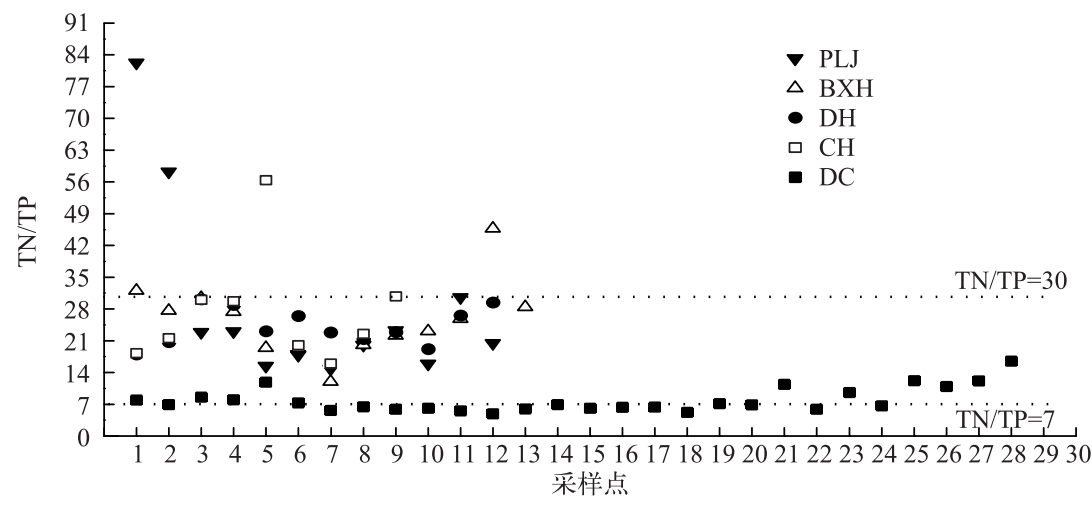

图 6 人滇河流及滇池水体的氮磷比分布

Fig.6 The distribution of TN/TP ratios in water of inflow rivers and Lake Dianchi 
浓度主要受农业面源污染影响,夏季强降雨引起的地表径流将农业生态系统中未被利用的氮素及其他污染 物带人河流造成氨氮污染 ${ }^{[38]}$, 其中, 第 8 个采样点 $\mathrm{NH}_{3}-\mathrm{N}$ 浓度达到最大, 说明该样点区域水体近期受到污 染最为严重 ${ }^{[39]}$. 城乡结合型河流 (宝象河) 和城市纳污型河流 (盘龙江) 的污染主要来自生活污水和工厂的 点源排放, 排放量常年基本保持稳定. 城市纳污型河流虽受人类活动影响较大, 但污染程度较小, 这与盘龙 江污染治理措施的加强 (河道清淤、水质治理) 和江河污染防控措施的实施有一定关系. 农业汇水区的大河 和柴河虽受人为活动干扰小, 但该区域具有传统农作物与养殖区广布的地理特征 ${ }^{[40]}$, 且夏季降雨相对集中 造成农业区暴雨径流水所占比重增加, 导致河流面源污染的影响程度大于城市、工业聚集等点源污染程度.

农田型河流 (大河) 和村镇型河流 (柴河) 中 $\mathrm{NO}_{3}^{-}-\mathrm{N}$ 浓度呈逐渐增加至平稳的变化趋势, 而城乡结合型 河流 (宝象河) 和城市纳污型河流 (盘龙江) 水体中 $\mathrm{NO}_{3}^{-}-\mathrm{N}$ 浓度总体维持平稳状态 (图 7b). 因为在农田河流 和村镇地区, 施用的多为氮肥, 但 $\mathrm{NH}_{3}-\mathrm{N}$ 中的铵态氮 $\left(\mathrm{NH}_{4}^{+}-\mathrm{N}\right)$ 很容易通过硝化作用转化成 $\mathrm{NO}_{3}^{-}-\mathrm{N}$, 而土壤胶 体一般带负电荷, 因此, $\mathrm{NO}_{3}^{-}-\mathrm{N}$ 不易被土壤吸附而容易随地表与地下径流进人河流 ${ }^{[41-42]}$, 从而导致农田型和 村镇型河流中的 $\mathrm{NO}_{3}^{-} \mathrm{N}$ 浓度较高. 工业生产废水和城市生活污水中含有大量的有机氮和氨氮, 有机氮的分 解会消耗水体中大量氧气, 导致 $\mathrm{NH}_{4}^{+}-\mathrm{N}$ 向 $\mathrm{NO}_{3}^{-}-\mathrm{N}$ 转化的硝化作用减缓, 同时由于缺氧强化了河流底部 $\mathrm{NO}_{3}^{-}-\mathrm{N}$ 的反硝化作用, 使 $\mathrm{NO}_{3}^{-}-\mathrm{N}$ 浓度进一步降低 ${ }^{[43-4]}$, 从而使城乡结合型河流(宝象河) 和城市纳污型河流 (盘龙 江) 水体中 $\mathrm{NO}_{3}^{-}-\mathrm{N}$ 浓度相对较低.
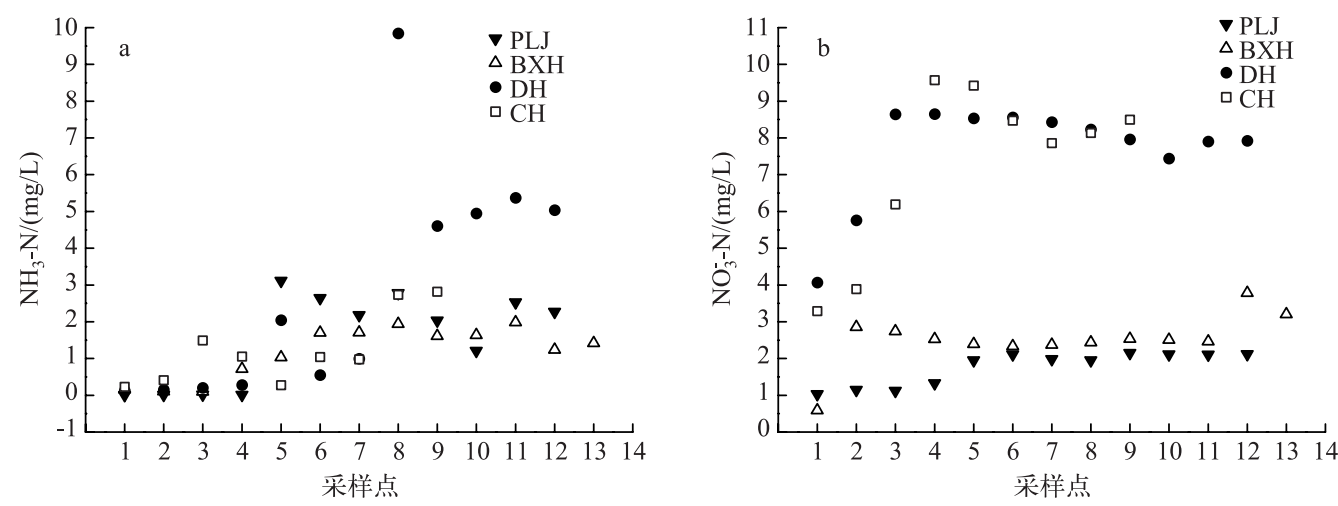

图 7 滇池 4 类人湖河流水体中氨氮和硝态氮浓度

Fig.7 Ammonia nitrogen and nitrate nitrogen concentrations in water of four different kinds of inflow rivers from Lake Dianchi

\section{3 入滇河流与滇池湖体氮、磷营养盐对比分析}

北部人滇河流水体中 $\mathrm{TN}$ 平均浓度为 $8.23 \mathrm{mg} / \mathrm{L}, \mathrm{TP}$ 平均浓度为 $0.38 \mathrm{mg} / \mathrm{L}$; 南部人滇河流水体中 $\mathrm{TN}$ 平 均浓度为 $20.24 \mathrm{mg} / \mathrm{L}$, TP 平均浓度为 $0.84 \mathrm{mg} / \mathrm{L}$. 南部人滇河流水体中 TN、TP 浓度是北部人滇河流的 2 倍 多. 而滇池北部水体中 TN 浓度在 $3.47 \sim 5.39 \mathrm{mg} / \mathrm{L}$ 之间, TP 浓度在 $0.34 \sim 0.47 \mathrm{mg} / \mathrm{L}$ 之间. 滇池南部水体中 $\mathrm{TN}$ 浓度在 1.14 3.46 mg/L 之间, 其 TP 浓度在 0.21 0.32 mg/L 之间 (图 3、5). 滇池水体 $\mathrm{TP} 、 \mathrm{TN}$ 浓度由北部 向南衰减, 与卢少勇等 ${ }^{[45]}$ 的研究结论一致, 但北部人滇河流比南部人滇河流污染小的结果与其研究不一致, 因此, 我们推测滇池北部富营养化的主要影响因素是内源释放, 水体的富营养化水平很大程度上受底泥向 水体释放的氮、磷营养盐的影响 ${ }^{[46-47]}$. 结合湖泊水体沉积学理论, 可能原因有: (1) 滇池地区常年盛行西南 风 ${ }^{[48]}$, 南部水体中的 TN、TP 随水流和风的扰动向北部集聚. (2) 与滇池特定的水动力、地形构造 ${ }^{[49]}$ 有关. (3) 滇池南部多为磷矿区, 如柴河流域周边磷矿分布广泛, 磷矿石含钙量较高, 而沉积物无机磷主要以钲磷 化合物形式沉积 ${ }^{[50]}$. 滇池西南部磷的吸附性沉积, 导致磷浓度降低. 为此, 在今后的滇池水体富营养化研究 中,应对滇池内源释放进行深人研究. 


\section{4 结论}

1) 滇池 4 类典型人湖河流水体中 $\mathrm{TN} 、 \mathrm{TP}$ 污染均较严重, $\mathrm{NO}_{3}^{-}-\mathrm{N}$ 为氮的主要赋存形式, 具有面源、点源双 重污染的特征.

2) 4 类典型人湖河流中, TN、TP 平均浓度大小顺序为:农田型河流 (大河) $>$ 村镇型河流 (柴河) > 城乡结 合型河流 (宝象河) >城市纳污型河流( 盘龙江).

3 ) 夏季各条河流水质整体上适合浮游藻类的生长,氮元素是滇池浮游植物生长的主要限制因子.

4 ) 滇池水体 TN、TP 平均浓度的空间分布存在差异, 总体上呈现出由滇池北部向南部逐渐递减的趋势, 该特征与外源污染物的输人状况相反. 内源释放是滇池北部水体富营养化的主要影响因素, 值得进一步深 人研究.

\section{5 参考文献}

[ 1 ] Zhang H, Huang GH. Assessment of non-point source pollution using a spatial multicriteria analysis approach. Ecological Modelling, 2011, 222 : 313-321.

[ 2 ] Schaffner M, Bader HP, Scheidegger R. Modeling the contribution of point sources and non-point sources to Thachin River water pollution. Science of the Total Environment, 2009, 407: 4902-4915.

[ 3 ] Zhang Shaohao, Wu Hongjuan, Cui Bo et al. Preliminary study on control of algaeblooms by hyriopsis cumingii lea. Acta Hydrobiologica Sinica, 2007, 31(5) : 760-762(in Chinese). [张绍浩, 邬红娟, 崔博等.利用三角帆蚌控制水华的初 步研究. 水生生物学报, 2007, 31(5): 760-762.]

[ 4 ] Cai Qinghua, Hu Zhengyu. Studies on eutrophication problem and control strategy in the three gorges reservoir. Acta Hydrobiologica Sinica, 2006, 30(1): 7-11 (in Chinese with English abstract). [ 蔡庆华, 胡征宇. 三峡水库富营养化问题与 对策研究. 水生生物学报, 2006, 30(1): 7-11.]

[ 5 ] Qin BQ, Yang LY, Chen FZ et al. Mechanism and control of lake eutrophication. Chinese Science Bulletin, 2006,51 (19) : 2401-2412.

[ 6 ] Padisak J, Reynolds CS. Selection of phytoplankton associations in Lake Balaton, Hungary, in response to eutrophication and restoration measures, with special reference to cyanoprokaryotes. Hydrobiologia, 1998, 384: 41-53.

[ 7 ] Yu Xiaogan, Josef Nipper, Yan Nailing et al. Recommendations of eutrophication control of Taihu Lake from an international view. Acta Geographica Sinica, 2007, 62(9) : 889-906(in Chinese with English abstract).[虞孝感, Josef Nipper, 燕乃玲. 从国际治湖经验探讨太湖富营养化的治理. 地理学报, 2007, 62(9) : 899-906. ]

[ 8 ] Guo Huaicheng, Wang Xinyu, Yi Xuan. Study on eutrophication control strategy based on the succession of water ecosystem in the Dianchi Lake. Geographical Research, 2013, 32(6): 998-1006(in Chinese with English abstract). [ 郭怀成, 王心宇, 伊璇. 基于滇池水生态系统演替的富营养化控制策略. 地理研究, 2013, 32(6) : 998-1006.]

[ 9 ] Zhu Jun, Dong Hui, Wang Shoubing et al. Sources and quantities of main water pollution loads released into Three-Gorge Reservoir of the Yangtze River. Advances in Water Science, 2006, 17(5) : 709-713(in Chinese with English abstract). [ 朱 骏, 董辉, 王寿兵等. 长江三峡库区干流水体主要污染负荷来源及贡献. 水科学进展, 2006, 17(5): 709-713.]

[10] Guo Huaicheng, Sun Yanfeng. Characteristic analysis and control strategies for the eutrophicated problem of the Lake Dianchi. Progress in Geography, 2002, 21(5): 500-506(in Chinese with English abstract). [ 郭怀成, 孙延枫. 滇池水体富 营养化特征分析及控制对策探讨. 地理科学进展, 2002, 21(5): 500-506.]

[11] Gao L, Zhou JM, Yang H et al. Phosphorus fractions in sediment profiles and their potential contributions to eutrophication in Dianchi Lake. Environmental Geology, 2005, 48: 835-844.

[12] Xiao M, Wu F, Zhang R et al. Temporal and spatial variations of low-molecular-weight organic acids in Dianchi Lake, China. Journal of Environmental Sciences, 2011, 23( 8) : 1249-1256.

[13] Wang Lifang, Xiong Yongqiang, Wu Fengchang et al. The eutrophication process of Lake Dianchi: evidences from the $\delta^{13} \mathrm{C}$ value of the bound $\mathrm{nC}_{16: 0}$ fatty acid. J Lake Sci, 2009, 21(4) : 456-464(in Chinese with English abstract). DOI: 10. $18307 / 2009.0402$. [王丽芳, 熊永强, 吴丰昌等. 滇池的富营养化过程: 来自结合态脂肪酸 $\mathrm{C}_{16: 0} \delta^{13} \mathrm{C}$ 的证据. 湖泊 科学, $2009,21(4): 456-464$. ] 
[14] Wu Deling, Qian Biao, He Linhui. Contributing factor analysis of eutrophication of Dianchi Lake. Research of Environmental Science, 1992, 5(5): 26-28(in Chinese with English abstract). [ 吴德玲, 钱彪, 何琳晖. 滇池富营养化成因分析. 环境科学研究, 1992, 5(5): 26-28.]

[15] Kong Yan, He Shuzhuang, Hu Bin et al. The settlement and transfer rule of phosphorus in stormwater runoff from phosphorus-rich area in Dianchi Watershed. Acta Scientiae Circumstantiae, 2012, 32(9) : 2160-2166(in Chinese with English abstract). [ 孔燕, 和树庄, 胡斌等. 滇池流域富磷地区暴雨径流中磷素的沉降及输移规律. 环境科学学报, 2012, 32(9) : 2160-2166. ]

[16] Liu Yong, Yang Pingjian, Sheng Hu et al. Watershed pollution prevention planning and eutrophication control strategy for Lake Dianchi. Acta Scientiae Circumstantiae, 2012, 32(8) : 1962-1972 (in Chinese with English abstract). [刘永, 阳平 坚, 盛虎等. 滇池流域水污染防治规划与富营养化控制战略研究. 环境科学学报, 2012, 32(8): 1962-1972.]

[ 17] Wang Hongmei, Chen Yan. Change trend of eutrophication of Dianch Lake and reason analysis in recent 20 years. Environmental Science Survey, 2009, 28(3) : 57-60 (in Chinese with English abstract). DOI: 10. 13623/2009. 03012. [王红 梅, 陈燕. 滇池近 20a 富营养化变化趋势及原因分析. 环境科学导刊, 2009, 28(3): 57-60.]

[18] Liu Yong, Zhu Yuanrong, Gong Xiaofeng et al. Sedimentary records of accelerated eutrophication in Dianchi Lake over the recent decades. Research of Environmental Sciences, 2012, 25: 1236-1242(in Chinese with English abstract). [刘勇, 朱 元荣, 弓晓峰等. 滇池近代富营养化加剧过程的沉积记录. 环境科学研究, 2012, 25: 1236-1242.]

[19] Wang Jiayin, Zhang Shitao, Wang Mingyu et al. Temporal and spatial distribution of groundwater nitrogen pollution and influence factors in Dahe river catchment in Dianchi watershed. Journal of Graduate University of Chinese Academy of Sciences, 2013, 30 (3) : 339-346(in Chinese with English abstract). [王佳音, 张世涛, 王明玉等. 滇池流域大河周边地 下水氮污染的时空分布特征及影响因素分析. 中国科学院研究生院学报, 2013, 30(3) : 339-346.]

[20] He Zongjian, Xiong Qiang, Jiao Lixin et al. Characteristics and bioavailability of dissolved organic phosphorus from different sources of Lake Dianchi in summer. China Environmental Science, 2014, 34(12): 3189-3198 (in Chinese with English abstract). [ 何宗健, 熊强, 焦立新等. 夏季滇池不同来源溶解性有机磷特征及其生物有效性. 中国环境科 学, 2014, 34(12): 3189-3198.]

[21] Li Yuexun, Xu Xiaomei, He Jia et al. Point source pollution control and problem in Lake Dianchi basin. J Lake Sci, 2010, 22(5): 633-639 (in Chinese with English abstract). DOI : 10.18307/2010.0502. [李跃勋, 徐晓梅, 何佳等. 滇 池流域点源污染控制与存在问题解析. 湖泊科学, 2010, 22(5):633-639.]

[22] Jin Shuquan, Zhu Xiaoli, Zhou Jinbo et al. Pollution characteristics of nitrogen and phosphorus in typical reaches in rural area of Ningbo. Journal of Soil and Water Conservation, 2010, 24(1) : 106-108 (in Chinese with English abstract). [ 金树 权, 朱晓丽, 周金波等. 宁波农村地区典型河流氮磷污染特征分析. 水土保持学报, 2010, 24(1): 106-108.]

[23] Wang ZJ, Hui LG. Evaluating the effectiveness of routine water quality monitoring in Miyun reservoir based on geostatistical analysis. Environmental Monitoring and Assessment, 2010, 160(1/2/3/4) : 465-478.

[24] State Environmental Protection Administration. The surface water environmental quality standard of the People's Republic of China (GB 3838-2002). Beijing: China Environmental Science Press, 2002(in Chinese).[国家环境保护总局. 中华 人民共和国地表水环境质量标准 (GB 3838-2002) 北京: 中国环境科学出版社, 2002.]

[25] Quirós R. The relationship between nitrate and ammonia concentrations in the pelagic zone of lakes. Limnetica, 2003,22 $(1 / 2): 37-50$.

[26] Luo Guyuan, Bu Faping, Xu Xiaoyi et al. Dynamics of TN and TP in the backwater region of the Linjiang River in the Three Gorge Reservoir. Journal of Civil, Architectural \& Environmental Engineering, 2009, 31(5): 106-111 (in Chinese with English abstract). [罗固源, 卜发平, 许晓毅等. 三峡库区临江河回水区总氮和总磷的动态特征. 土木建筑与环 境工程, 2009, 31(5) : 106-111.]

[27] Lei Pei, Zhang Hong, Shan Baoqing. Dynamic characteristics of nitrogen and phosphorus in the representative input tributaries of Danjiangkou Reservoir. Environmental Science, 2012, 33(9) : 3038-3045 (in Chinese with English abstract). [ 雷 沛, 张洪, 单保庆. 丹江口水库典型人库支流氮磷动态特征研究. 环境科学, 2012, 33(9) : 3038-3045.]

[28] Li Zhe, Guo Jinsong, Fang Fang et al. Potential impact of TN/TP ratio on the cycling of nitrogen in Xiaojiang backwater area, Three Gorges Reservoir. J Lake Sci, 2009, 21(4) : 509-517 (in Chinese with English abstract). DOI: 10.18307/ 2009.0409. [李哲, 郭劲松, 方芳等. 三峡水库小江回水区不同 TN/TP 水平下氮素形态分布和循环特点. 湖泊科 学, 2009, 21(4) : 509-517.] 
[29] Peng Jinxin, Chen Huijun eds. Prevention and control of eutrophication and water quality. Beijing: China Environmental Science Press, 1988: 15-47 (in Chinese). [ 彭近新, 陈慧君. 水质富营养化与防治. 北京: 中国环境科学出版社, 1988: 15-47.]

[30 ] Wen Hang, Cai Jialiang, Su Yu et al. Characteristics of periphytic algal community and its relationship with aquatic environmental factors in streams of Lake Dianchi watershed in wet season. J Lake Sci, 2011, 23(1) : 40-48 (in Chinese with English abstract). DOI: 10.18307/2011.0107. [文航, 蔡佳亮, 苏玉等. 滇池流域人湖河流丰水期着生藻类群落特征 及其与水环境因子的关系. 湖泊科学, 2011, 23(1): 40-48.]

[31] Li Xing, Yang Yang, Qiao Yongmin et al. Temporal-spatial distribution and source of nitrogen in main stream of Dongjiang River. Acta Scientiae Circumstantiae, 2015, 35(7) : 2143-2149(in Chinese with English abstract). [李星, 杨杨, 乔永 民等. 东江干流水体氮的时空变化特征及来源分析. 环境科学学报中, 2015, 35(7) : 2143-2149.]

[32] Liu Zhonghan, He Bin, Wang Yiming et al. Effects of rainfall runoff on total nitrogen and phosphorus flux in different catchments of Dianchi Lake, Yunnan, China. Geographical Research, 2004, 23(5) : 593-604(in Chinese with English abstract). [ 刘忠翰, 贺涁, 王宜明等. 滇池不同流域类型降雨径流对河流氮磷人湖总量的影响. 地理研究, 2004, 23(5) : 593-604.]

[33] Li Xiaoming, Yang Shuping, Zhang Yu et al. Planktonic algae diversity and its water quality monitoring in Chai River, Baoxiang River and Panlong River, three inflow river of Dianchi Lake. Journal of Yunnan University, 2014, 36( 6) : 950958 (in Chinese with English abstract). [李晓铭, 杨树平, 张宇等. 人滇池河流柴河、宝象河与盘龙江浮游藻类多样 性调查及其水质监测研究. 云南大学学报: 自然科学版, 2014, 36(6) : 950-958.]

[34] Sheng ZY, Liu RM, Ding XW et al. The characteristics of non-point source pollution and its change rules in the upper Yangtze River. Beijing: Science Press, 2008.

[35] Nie Zeyu, Liang Xinqiang, Xing Bo et al. The current water trophic status in Tiaoxi River of Taihu Lake watershed and corresponding coping strategy based on N / P ratio analysis. Acta Ecologica Sinica, 2012, 32(1) : 48-55(in Chinese with English abstract). [聂泽宇, 梁新强, 邢波等. 基于氮磷比解析太湖苕溪水体营养现状及应对策略. 生态学报, 2012, 32(1): 48-55.]

[36] Zhang Guoming, Gao Yang, Li Zhaojun et al. Study on non-point resource dynamic transport of Lanhe Watershed located in Fenhe River's upstream. Journal of Soil and Water Conservation, 2008, 22(2) : 102-106( in Chinese with English abstract). [张国明, 高扬, 李兆君等. 汾河上游岗河流域非点源输出动态研究. 水土保持学报, 2008, 22(2): 102-106. ]

[37] Liu Ruixiang, Chang Huili, Zhao Fuqiang et al. Flux dynamics of nitrogen and phosphorus in major input rivers of Zhangze Reservoir. Chinese Journal of Ecology, 2010, 29(3): 479-484(in Chinese with English abstract). [刘瑞祥, 常惠丽, 赵 富强等. 漳泽水库主要人库河流氮、磷营养盐特征. 生态学杂志, 2010, 29(3): 479-484.]

[38] Zhang Ying. Pollution status and characteristics of ammonia nitrogen in the river of Hubei province. Environmental Science \& Technology , 2001, 24 (supplement) : 30-31 (in Chinese). [张莺. 湖北省河流中氨氮的污染状况与特征. 环境科学 与技术, 2001, 24(增刊) : 30-31.]

[39] Zhai Min, Yue Xitong, Song Aiqin. A research on hygienic status of rural drinking water. J Environ Occup Med, 2006,23 (1) : 64-65 (in Chinese with English abstract). [ 翟敏, 岳喜同, 宋爱芹. 济宁市农村生活饮用水卫生状况调查. 环境 与职业医学, 2006, 23(1): 64-65.]

[40] Zhu Xiaoqi, Hu Zhengyi, Wang Huihui et al. Comparison of nitrogen loss between controlled release urea and common urea in vegetable soils at Chaihe Catchment of Dianchi Lake. Journal of Agricultural Science and Technology, 2014, 16(6) : 109-116( in Chinese with English abstract). [ 朱晓琦, 胡正义, 王惠惠等. 滇池柴河流域蔬菜地土壤施用控释尿素与 普通尿素的氮损失比较. 中国农业科技导报, 2014, 16(6): 109-116.]

[41] Mc Dowell WH, Asbury CE. Export of carbon, nitrogen, and major ions from three tropical montane watersheds. Limnology and Oceanography, 1994, 9 (1): 111-125.

[42] Williard KWJ, Dewalle DR, Edwards PJ. Influence of bedrock geology and tree species composition on stream nitrate concentrations in mid-Appalachian forested watersheds. Water Air and Soil Pollution, 2005, 160(1/4) : 55-76.

[43] Sharma B, Ahlert RC. Nitrification and nitrogen removal. Water Research, 1977, 11(10) : 897-925.

[44] Seitzinger SP. Denitrification in freshwater and coastal marine ecosystems: Ecological and geochemical significance. Limnology and Oceanography, 1988, 33 (4) : 702-724. 
[45] Lu Shaoyong, Cai Minmin, Jin Xiangcan et al. Spatial distribution of nitrogen species in sediment of lakeside zone of Lake Dianchi. Ecology and Environmental Sciences, 2009, 18(4) : 1351-1357(in Chinese with English abstract). [卢少勇, 蔡 珢敏, 金相灿等. 滇池湖滨带沉积物氮形态的空间分布. 生态环境学报, 2009, 18(4) : 1351-1357.]

[ 46] Sun Quan, Han Xiuyun, Guo Xiaoning. Study on phosphorus adsorption and application by the major soils of Ningxia. Chinese Journal of Soil Science, 2003, 34(5) : 418-421 (in Chinese with English abstract). [ 孙权, 韩秀云, 郭晓宁. 宁夏 主要土壤的磷酸吸附特征及影响因素.土壤通报, 2003, 34(5): 418-421.]

[47] He Jia, Xu Xiaomei, Yang Yan et al. Problems and effects of comprehensive management of water environment in Lake Dianchi. J Lake Sci, 2015, 27(2) : 195-199(in Chinese with English abstract). DOI: 10.18307/2015.0201.[何佳, 徐晓 梅, 杨艳等. 滇池水环境综合治理成效与存在问题. 湖泊科学, 2015, 27(2): 195-199.]

[48] Yao Ping, Zhao Fuzhu, Xiao Hongyun. Research of climate character over Dianchi Lake Basin. Environmental Science Survey, 2009, 28 (supplement) : 8-10(in Chinese with English abstract). DOI: 10.13623/2009.s1.001. [姚平, 赵付竹, 夏 红云. 滇池流域气候特征研究. 环境科学导刊, 2009, 28(增刊) : 8-10.]

[49] Meng Yayuan, Wang Shengrui, Jiao Lixin et al. Characteristics of nitrogen pollution and the potential mineralization in surface sediments of Dianchi Lake. Environmental Science, 2015, 36(2) : 471-480( in Chinese with English abstract). [孟亚 媛, 王圣瑞, 焦立新等. 滇池表层沉积物氮污染特征及其潜在矿化能力. 环境科学, 2015, 36(2): 471-480.]

[50] Gao Li, Yang Hao, Zhou Jianmin et al. Adsorption of phosphate and mineral characteristic in sediment in Dianchi Lake. Journal of Agro-Environment Science, 2004, 23(2) : 259-262 (in Chinese with English abstract). [ 高丽, 杨浩, 周健民 等. 滇池沉积物磷酸盐吸附和矿物学特征的研究. 农业环境科学学报, 2004, 23(2): 259-262.] 